\title{
Reconstruction of flood events based on documentary data and transnational flood risk analysis of the Upper Rhine and its French and German tributaries since AD 1480
}

\author{
I. Himmelsbach ${ }^{1}$, R. Glaser ${ }^{1}$, J. Schoenbein ${ }^{1}$, D. Riemann ${ }^{1}$, and B. Martin ${ }^{2}$ \\ ${ }^{1}$ Physical Geography, Albert-Ludwigs Universität Freiburg, Freiburg, Germany \\ ${ }^{2}$ CRESAT, University of Haut-Alsace, Mulhouse, France \\ Correspondence to: J. Schoenbein (johannes.schoenbein@geographie.uni-freiburg.de) \\ Received: 1 December 2014 - Published in Hydrol. Earth Syst. Sci. Discuss.: 7 January 2015 \\ Revised: 11 September 2015 - Accepted: 23 September 2015 - Published: 14 October 2015
}

\begin{abstract}
This paper presents the long-term analysis of flood occurrence along the southern part of the Upper Rhine River system and of 14 of its tributaries in France and Germany covering the period starting from $1480 \mathrm{BC}$. Special focus is given on the temporal and spatial variations of flood events and their underlying meteorological causes over time. Examples are presented of how long-term information about flood events and knowledge about the historical aspect of flood protection in a given area can help to improve the understanding of risk analysis and therefor transnational risk management. Within this context, special focus is given to flood vulnerability while comparing selected historical and modern extreme events, establishing a common evaluation scheme.

The transnational aspect becomes especially evident analyzing the tributaries: on this scale, flood protection developed impressively different on the French and German sides. We argue that comparing high technological standards of flood protection, which were initiated by the dukes of Baden on the German side starting in the early 19th century, misled people to the common belief that the mechanical means of flood protection like dams and barrages can guarantee the security from floods and their impacts. This lead to widespread settlements and the establishment of infrastructure as well as modern industries in potentially unsafe areas until today. The legal status in Alsace on the French side of the Rhine did not allow for continuous flood protection measurements, leading to a constant - and probably at last annoying - reminder that the floodplains are a potentially unsafe place to be. From a modern perspective of flood risk management, this leads to a significant lower aggregation of value in the floodplains of
\end{abstract}

the small rivers in Alsace compared to those on the Baden side - an interesting fact - especially if the modern European Flood directive is taken into account.

\section{Introduction}

The knowledge about the occurrence of floods in historical times, their meteorological causes and their distribution within the (hydrological) year does provide a deeper understanding of the natural variability of the severity of flood events by providing long-term knowledge about changes in the causes, frequencies and gravity of the floods as it had recently been discussed in detail, e.g., by Seidel and Bárdossy (2010) or Grünewald (2010). Pursuing the ideas from Glaser et al. (2010) to research climate responses of rivers and creeks with small catchments, this paper focusses on the tributaries of the Rhine within the Upper Rhine Rift. Flood research on smaller rivers as presented in this paper complements the research related to larger river systems for two main reasons. Creeks and small rivers show a more direct response to the atmospheric forcing. Similarly, they are much more susceptible to changes of land use or alterations of the floodplain due to an increase of settlements and infrastructure, as those alternations also directly affect discharge.

From a perspective of transnational risk research, those creeks and small rivers are equally interesting to look at. The flood risk management of these smaller catchments lies within the responsibility of smaller communities while the large river systems are under control of larger and stronger administrative units. This however sums up the similarities 
between the French and German sides: due to its roots in the Roman jurisdiction, the state of France had no rights on the non-navigable rivers and therefore could not develop plans of flood protection. The German tributaries, however, stood under the undisputed sovereign territory of the Dukes of Baden since the 18th century, who opted for technical flood protection with dams and barrages to protect the floodplains.

This administrative difference concerning flood control and management plays an important role in modern flood risk management. In France flood risk management on nonnavigable rivers is handled by PPRIs (Plan de prévention du risque d'inondation) which are negotiated by the communities and the responsible parts of the administration. Their goal is to determine the area with a risk of being flooded along the examined rivers and to discriminate between zones where different human activities can be allowed or have to be forbidden.

In Germany (especially in Baden-Württemberg) the flood risk management of smaller tributaries (water bodies of category II) resides with the legal responsibility of communities while the large non-navigable rivers (water bodies of category I) are under control of stronger administrative units like regional councils. Still, the category of water body changes from category II (the upper parts of the river) into category I at positions which were specified according to the master plan of Johann Gottfried Tulla (1770-1828) in the 19th century.

This study presents the results from the project TRANSRISK, which was realized between 2008 and 2011 in collaboration between CRESAT (Centre de Recherche sur les Economies, les Sociétés, les Arts et les Techniques) of the University de Haute Alsace in Mulhouse funded by the French Agence Nationale de la Recherche (ANR07-FRAL-025) and the Department of Physical Geography of the Albert-Ludwigs-Universität Freiburg founded by the Deutsche Forschungsgemeinschaft (DFG-Gl 358/5-1).

\section{Study area}

The study area is located within the Upper Rhine Rift and stretches approx. $110 \mathrm{~km}$ between Basel, Switzerland, and Strasbourg, France, including the edges of the Black Forest and Vosges Mountains (Table 1). The elevation of the Upper Rhine Rift ranges from about $250 \mathrm{~m}$ a.s.l. in Basel to $130 \mathrm{~m}$ a.s.1. at Strasbourg. The highest mountaintops of the region are the Feldberg (1493 ma.s.1.) in the Black Forest and the Grand Ballon d'Alsace (1424 ma.s.1.) in the Vosges. The area is located in the midlatitudes, a zone of predominant westerly winds and in the transition of maritime too continental climate. The climate is moderately mild due to its location around $48^{\circ} \mathrm{N}$ and decent protection against cool air masses from the surrounding low mountain ranges. Warm southwesterly winds which originate from the Western Mediterranean region can reach the area only moderately modified through the Belfort Gap. This however might only happen in less than $10 \%$ of the year. The westerly winds and approx. $1000 \mathrm{~m}$ of mean height difference between the rims and the valley floor account for a heterogeneous distribution of precipitation between the Vosges Mountains and the Black forest as well as within the Upper Rhine Valley. Precipitation varies greatly from as little as $550 \mathrm{~mm} \mathrm{a}^{-1}$ at Colmar leeward of the Vosges Mountains to more than $2200 \mathrm{~mm} \mathrm{a}^{-1}$ at the summits. Two precipitation maxima can be identified in the course of the year: one in July and another in December. The July maximum is generated mainly by convective rainfall, resulting usually from thunderstorms.

Large parts of the study area belong to the European region "Regio TriRhena" and nearly the whole study area is also part of the Trinational Metropolitan Region Oberrhein (TMO-MRO) forming a multicore, trinational conurbanization combining more than six million people and industrial hot spots. Both concepts try to improve the transnational collaboration on the fields of science, commerce, technology and politics as well as civil societies. Strasbourg is one of the European capitals. Historically, the researched area has been affected by many territorial conflicts since the 17 th century. Between 1871 and 1919 and again from 1940 to 1945 Alsace was occupied by Germany. As far as flood control management is concerned, those different administrations tried to realize their own concepts and ideas; however, both administrations were not been able to come up with and enforce a master plan for flood protection due to traditional water rights (see below).

\section{Methods and data}

Within the TRANSRISK project, the Rhine between Basel and Strasbourg and 14 of its tributaries have been analyzed: in Alsace the rivers Largue, Ill, Doller, Thur, Fecht and Lauch; and in Baden the rivers Wiese, Klemmbach, Kander, Neumagen/Möhlin, Dreisam, Elz, Schutter and Kinzig.

For none of those tributaries had hitherto a flood research or a comparative survey regarding flood protection measures been conducted. So the first interest was to reconstruct the flood events between 1480 and 2007 as detailed as possible, their underlying meteorological causes together with their spatiotemporal variation. Our approach followed the method of critical source analysis, which can be regarded as well established in the field of historical climatology (Pfister, 1985; Glaser and Stangl, 2003; Jacobeit et al., 2006; Glaser et al., 2010; Wetter et al., 2011; Himmelsbach, 2014). Following these well-established principles of critical source analysis, the multitude of information gathered had been critically reviewed in a hermeneutic approach due to their informational content mainly analyzing diction of the source as well as additionally information about the author like level of education or social environment, intention, etc., which might have influenced or motivated the writings. Equally important is 
the cross-validation within different sources describing the same event. Another valuable aspect for critical source analysis and evaluation is the described impact of the floods and the damages, which are very often given in detailed images. Of course there is always a time shift in historical records, the kind, where such detailed information decreases through time. Even though more than 2800 flood events have been identified by a total of over 4000 references, cross validation becomes more difficult for early events. Therefor, the level of uncertainty diminishes through time, which has to be taken into account for all given results.

The use and usefulness of information derived from historical sources is an ongoing discussion within the scientific community and even more so within the hydraulic engineering community. In contrast to measurement data, historical data never promises modeling results with seemingly mathematical exactness. Dealing with historical information always means dealing with uncertainties, which is also a fundamental issue for all kinds of statistical analyses. blackbox[CE]The meaning of this sentence is not very clear, please revise it so that the meaning is clearer.But besides loads of additional information which might be regarded useful for some research questions historical data offer, so the methodology of critical source analysis had correctly been applied, sound information on the occurrence of past events and allow for a reliable estimation of the magnitude of the past flood event. That those insights offer added value was proven amongst others by the work of Bürger et al. (2006) for the River Neckar and by Grünewald (2010) for the River Elbe where the return intervals of flood events had to be recalculated due to data originated from historical sources.

As data sources of written evidence, flood marks, drawings, flood maps, newspapers, gauge data and contemporaneous administrative reports and chronicles have been considered. All possible information regarding flood events, their duration and spatial extent or mitigation strategies for helping those who were affected have been extracted. To estimate and rank the intensity of the flood event, a classification scheme has been applied in which the intensity and spatial dimension as well as the impacts as primary indicators, the duration as secondary indicators and the mitigation strategies as tertiary indicators were taken into account (Table 1). With this scheme it is possible to differentiate between smaller, medium, strong and extreme events (see Glaser et al., 2012). For some case studies, detailed information on impacts were used to analyze and quantify the vulnerability. To compare the spatial and economic dimensions of single selected historical events with modern events, the economic values have been standardized.

Gathering information on extreme events in historical sources is generally not overly difficult as catastrophic events are of a certain interest and widely recorded. However, in as far as medium or small events are concerned, information becomes more sparse and a correct differentiation between them is difficult.
The availability of sources describing flood events on the French and the German sides show some distinct differences. In Alsace, data on flood events is provided by a long tradition of writing chronicles, which was shared by municipalities, abbeys or individuals and holds until the 19th century. Examples could be the town chronicles of Murbach, Mulhouse, Ensisheim, Colmar, Sélestat, Ribeauvillé or Strasbourg. Famous is the chronicle from the abbey of Thann by Malachias Tschamser (1678-1742), who reports on extremes also outside of Alsace. Even so, gauging data is sparse in Alsace until the 1870s, the fact that all creeks discharge into the River Ill before discharging in the much bigger River Rhine allows for possible cross-validation of flood events as the flood wave can be tracked on its way downstream and chronicles (normally) state the villages and towns affected. The floods of 1511 (mentioned by 14 sources) or 1529 (mentioned by six sources) can be used as examples. Gauging data is available in Alsace from 1870 to the 1930s and from the 1950s onward.

The situation is different on the German side. Here, chronicles came "out of style" since the Middle Ages and the few which were written mainly concentrate on reporting political events. Even by researching alternative sources like transcripts of the city councils or the building authorities, it is not possible to gather the same quantity of sources which are available in Alsace. The exceptions are the flood events of the River Rhine, which are often described in great detail by the chronicles of Switzerland especially from Bern and Basel, like the floods of summer 1480 and 1511 or December 1506. Especially for Basel, the information is exact enough to assess the biggest events (Wetter et. al. 2011). Following the idea of Johann Gottfried Tulla (1770-1828), Baden begun with the installation of official gauging stations during the early 19th century and expanded the measuring network to the tributaries during the 1820 s. In the early 1870 s the Duchy of Baden initiated the "Nachrichtendienst bei Hochwasser", a news service and which was activated in case of flood events which was to establish communication with the downstream communities in case of rising water levels. The related laws provide detailed information on the water level which had been regarded as dangerous.

With the 19th century, newspapers started to appear within the research area, which complemented the information about past flood events by providing a more widened information base.

A total of 2830 flood events were found in written sources, and gauge data and were evaluated within the research area (Table 2). In Germany a total of 1302 events have been identified with an emphasis on the 20th century. In France we identified 1201 events, and for the River Rhine 327 events could be found. We found more events in France for the time before the 19th century than for the German part of the research area. A main reason for that is the existence of many chronicles in Alsace and nearly none for the German part, which can be regarded as a result of the existence of more cities and monasteries in Alsace along the rivers and a deeper tradition 
Table 1. Study area including the researched rivers and actual administrative districts in France and Germany.

\begin{tabular}{|c|c|c|c|c|}
\hline Class & $\begin{array}{l}\text { Classification } \\
\text { (intensity and spatial } \\
\text { dimension) }\end{array}$ & $\begin{array}{l}\text { Primary indicators } \\
\text { (damages) }\end{array}$ & Secondary indicators (temporal structure) & $\begin{array}{l}\text { Tertiary indicators } \\
\text { (mitigation) }\end{array}$ \\
\hline-1 & No classification possible & No information & No information & No information \\
\hline 1 & $\begin{array}{l}\text { Small flood } \\
\text { Regulated rivers: up to } \\
\text { HQ20 equivalent }\end{array}$ & $\begin{array}{l}\text { Little damage: e.g., on bankside } \\
\text { fields and gardens; no bigger } \\
\text { damages named. }\end{array}$ & Short flood & $\begin{array}{l}\text { Little (local) } \\
\text { supporting measures }\end{array}$ \\
\hline 2 & $\begin{array}{l}\text { Above average, big or } \\
\text { supraregional flood } \\
\text { Regulated rivers: HQ20- } \\
\text { HQ100-equivalent }\end{array}$ & $\begin{array}{l}\text { Strong decline: damages on } \\
\text { bridges and bankside buildings; } \\
\text { flood protection systems like } \\
\text { dams or barrages are affected } \\
\text { or damaged; loss of cattle and } \\
\text { people; } \\
\text { morphodynamical processes. }\end{array}$ & Flooding of average duration to few days & $\begin{array}{l}\text { Coordinated supporting mea- } \\
\text { sures with participation of } \\
\text { regional organizations }\end{array}$ \\
\hline 3 & $\begin{array}{l}\text { Extreme/supraregional flood } \\
\text { of catastrophical dimension } \\
\text { Regulated rivers: bigger than } \\
\text { HQ100 equivalent }\end{array}$ & $\begin{array}{l}\text { Strong decline: severe } \\
\text { damages/destruction of } \\
\text { flood protection systems, bridges } \\
\text { and buildings; damages on the } \\
\text { bankside fields and gardens, loss } \\
\text { of cattle and people. }\end{array}$ & Long-lasting flooding (several weeks) & $\begin{array}{l}\text { Supraregional (national), coor- } \\
\text { dinated measures of } \\
\text { major extent. } \\
\text { The event is followed by long- } \\
\text { lasting discussions about } \\
\text { security and better prevention. } \\
\text { The flood event became part of } \\
\text { the long-term memory and } \\
\text { resides as a reference point. }\end{array}$ \\
\hline
\end{tabular}

of documenting personal histories ("Livres de raison"). On the other hand, we could identify many more flood events on the German side on a basis of gauge data because of the work of Johann Gottfried Tulla, who ordered the installation of gauging stations on every river, starting in 1816 , as a basis for his rectification plans. In contrast, the limits of the French water rights prohibited the rectification of the rivers in Alsace during the 19th century (see Sect. 5), there was no need to put gauges on the rivers and working with mobile devices seemed sufficient. This led to only a minor amount of data concerning water levels. During the German occupation (1871-1919) some stationary gauges had been active but were decommissioned by the French administration in the early 1930s (Table 2).

To make this impressive data set accessible to the interested scientific community and the public, the data will be presented on the collaborative research environment www. tambora.org.

\section{Results}

The highly spatiotemporal-resolved data set and the detailed information on damages and impacts on the society lead to two main interpretations. First, different types of spatial flood occurrences were classified into five major groups and the underlying meteorological causes were determined. There is evidence about the changes of these underlying causes and changes in seasonality of the flood occurrences in the context of the overall climatic change debate.

A second part deals with the vulnerability of HQ100 $\left(\mathrm{HQ}_{X}=\right.$ discharge with a statistical annuality of $X$ years $)$ events and the possibility of incorporation of historical information into modern, integrated flood risk management. There is also another example about technical alterations regarding the city of Mulhouse.

\subsection{The derivation of specific spatial patterns of floods}

In a first step, all flood events were clustered based on their spatial patterns. Five types can be identified: floods only on the River Rhine, floods on the River Rhine and all its tributaries, floods on the French tributaries, floods on the German tributaries and floods on the French and German tributaries. These types are described below (see Table 2 to Fig. 6).

Type 1: floods occur only on the River Rhine without involving its tributaries. Examples for that type are the floods of July 1343, June 1876, September 1881 and July 1910. The cause for this flood type is located in the Alps and/or in the Swiss midlands. For extreme summer events, high temperatures and long lasting rain, in addition to a quick snow-melt in the higher regions of the Alps, are in most cases the reasons for those events. In the hydrological winter half-year an early snowfall and afterwards a quick snowmelt in addition to longer and/or stronger rainfall are the meteorological conditions for extreme floods of the River Rhine. In other cases it might be $\mathrm{a} \mathrm{Vb}$ (the $\mathrm{Vb}$ weather regime describes one kind of cyclone track over Europe being characterized by a high susceptibility to trigger floods) weather situation, which causes heavy rainfall in the Swiss midlands (Wetter et al., 2011; Wetter and Pfister, 2011).

Type 2: floods that affect the River Rhine and all its tributaries in the study area at the same time. Examples are the floods of July 1480, December 1882 and January 1910. In 
Table 2. Classification scheme for flood events (meso-scale).

\begin{tabular}{lllllllll}
\hline River & 15 th & 16 th & 17 th & 18 th & 19 th & 20 th & 21 th & Total \\
\hline Ill & 6 & 37 & 28 & 74 & 116 & 210 & 18 & 489 \\
Fecht & 2 & 16 & 12 & 17 & 45 & 56 & 9 & 157 \\
Lauch & 3 & 21 & 11 & 16 & 26 & 38 & 9 & 124 \\
Thur & 5 & 28 & 18 & 16 & 39 & 30 & 3 & 139 \\
Doller & 3 & 13 & 9 & 16 & 28 & 43 & 8 & 120 \\
Largue & 2 & 14 & 8 & 27 & 43 & 60 & 18 & 172 \\
\hline Total France & 21 & 129 & 86 & 166 & 297 & 437 & 65 & 1201 \\
\hline Kinzig & 1 & 8 & 26 & 39 & 88 & 160 & 10 & 332 \\
Schutter & 1 & 3 & 4 & 2 & 21 & 32 & 5 & 68 \\
Elz & 1 & 6 & 4 & 23 & 53 & 96 & 5 & 188 \\
Dreisam & 1 & 3 & 10 & 22 & 57 & 115 & 10 & 218 \\
Neumagen/Möhlin & 2 & 3 & 3 & 8 & 15 & 115 & 10 & 156 \\
Klemmbach & 1 & 3 & 2 & 6 & 10 & 11 & 1 & 34 \\
Kander & 1 & 3 & 2 & 2 & 5 & 18 & 0 & 31 \\
Wiese & 1 & 3 & 8 & 14 & 60 & 176 & 11 & 237 \\
\hline Total Germany & 9 & 32 & 59 & 116 & 309 & 723 & 54 & 1302 \\
\hline Rhine & 28 & 81 & 41 & 28 & 86 & 59 & 4 & 327 \\
\hline Total amount & & & & & & & 2830 \\
\hline & & & & & & & \\
\hline
\end{tabular}

historic times, as well as recently, this flood type is characterized by the biggest spatial extent of heavy damages. For this reason it is necessary to give the meteorological causes of this type a special attention. Large-scale and intensive rainfall events and/or rain on a heavy snowpack characterize this type.

Type 3: this type only affects the French tributaries in Alsace. Examples are the floods of March 1876 and February and December 1999. Small-scale low-pressure systems with snowmelt characterize this type.

Type 4: this type only affects the German tributaries in Baden. An example is the flood of December 1991, which was a so-called "Christmas flood": the flow turns to the northwest and flows, as part of a cyclone family, and initiates an early Christmas thaw. The precipitation falls into the summit level of the average mountains as rain, which could not infiltrate into the frozen ground (Weischet and Endlicher, 2000).

Type 5: this type represents flood events, where only the French and German tributaries of the River Rhine are affected, but not the Rhine itself. Examples are the events of May 1872, February 1877, March 1896, December 1919, December 1947 and April 1983.

The spatial pattern types can be correlated with a prevailing weather situation and therefore are of specific interest for further climatological interpretation. This connection will be the subject of further research (see Jacobeit et al., 2003a, b). In the following section the changes in underlying meteorological causes through time is elaborated on.

\subsection{Changes in underlying meteorological causes and seasonality}

Everyone who deals with reconstructing and evaluating historical floods from historical data with hermeneutical methods has to determine indicators to differentiate the severity of the floods. Glaser and Stangl (2003) and Glaser et al. (2010) focused on the effects and the damage caused by floods. However, it is important not only to collect data about the consequences of the flood events, it is also important to record timing and, in case hints can be found, meteorological causes of the event. Often historical sources provide that kind of information, and their records might be useful to help in reconstructing the initial meteorological situation which led to the researched event. Based on meteorological information which further described the researched flood events, we tried to display the temporal development of meteorological causes of floods for some of the researched tributaries. To classify meteorological causes, the classification scheme from Bauer (1952) is used, which distinguishes five causes: convective and continuous rainfall, snowmelt, ice breakup and rain on snow.

A comparison of the meteorological causes which induced flood events on some selected tributaries shows that over the whole period snowmelt/rain on snow is the most important cause and is followed by long-lasting rainfall. Events which are triggered by convective rain are currently discussed in connection with a changing climate (REMO, 2006; Zebisch et al., 2005) played a less important role as well as icebreak. However, when comparing the meteorological causes of the 


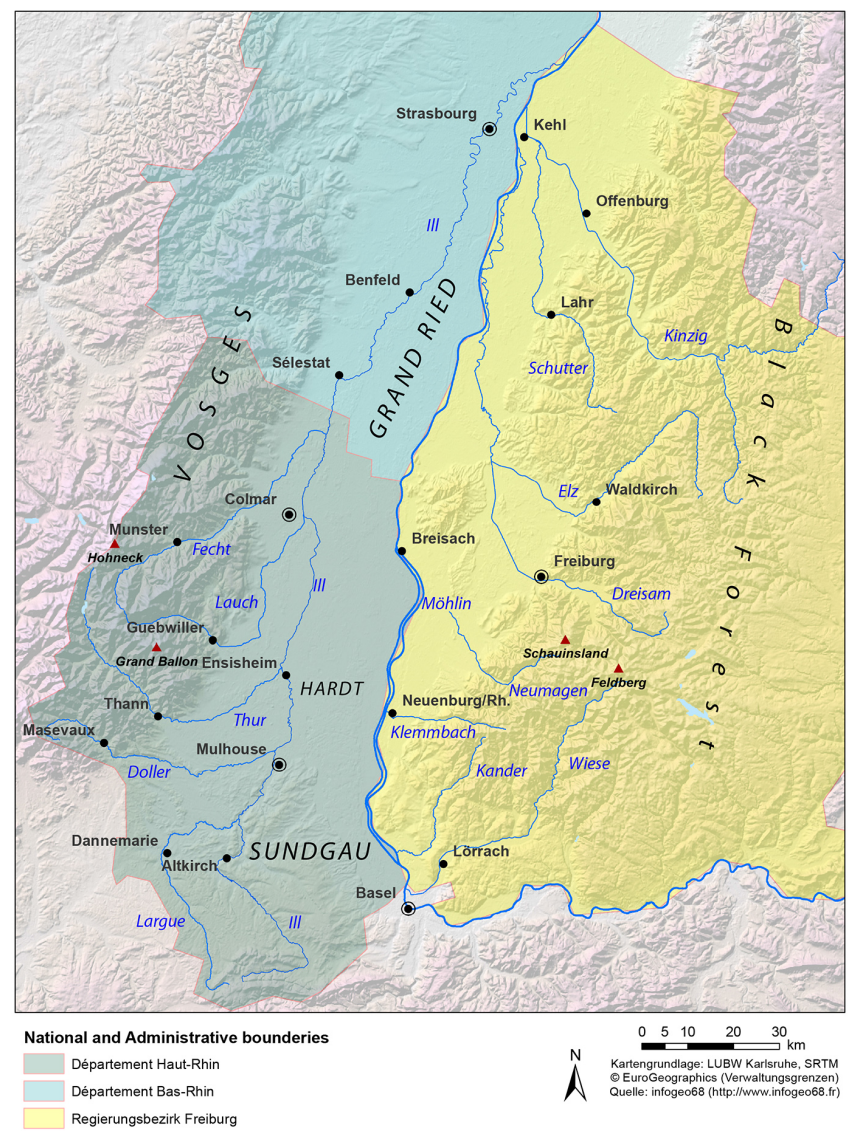

Figure 1. Study area including the researched rivers and actual administrative districts in France and Germany.

floods for the whole time period with those in the last five decades a distinct increase of convective rain events can be noted. It is reasonable to assume, that convective events gain intensity due to an increased hydrological cycle intensified by higher temperatures. Likewise, ice breakup has almost vanished as a reason for flood events in modern times. This however cannot only be attributed to generally higher temperatures but to a variety of reasons with the widespread loss of floodplains and induction of coolants being some major reasons. There is also an increase in snowmelt-related events. Floods caused by rain on snow show antithetic development. Changes in occurrence of floods caused by long-lasting rain range from pronounced to minor decrease (see Fig. 7).

In a second step the changes in seasonality of flood events happening at the River Rhine have been analyzed. Previous studies concluded that the runoff regime of the River Rhine changed during the 20th century from a main discharge during the hydrological summer to the hydrological winter halfyear (IKHR, 2007; IKSR, 2011). Our data suggests that only during a period lasting from the 1820 s to the 1860 s the River Rhine displayed a phase with an accentuated and rather unusual occurrence of summer floods. That event might be linked to the ending of the Little Ice Age (LIA) around 1850.

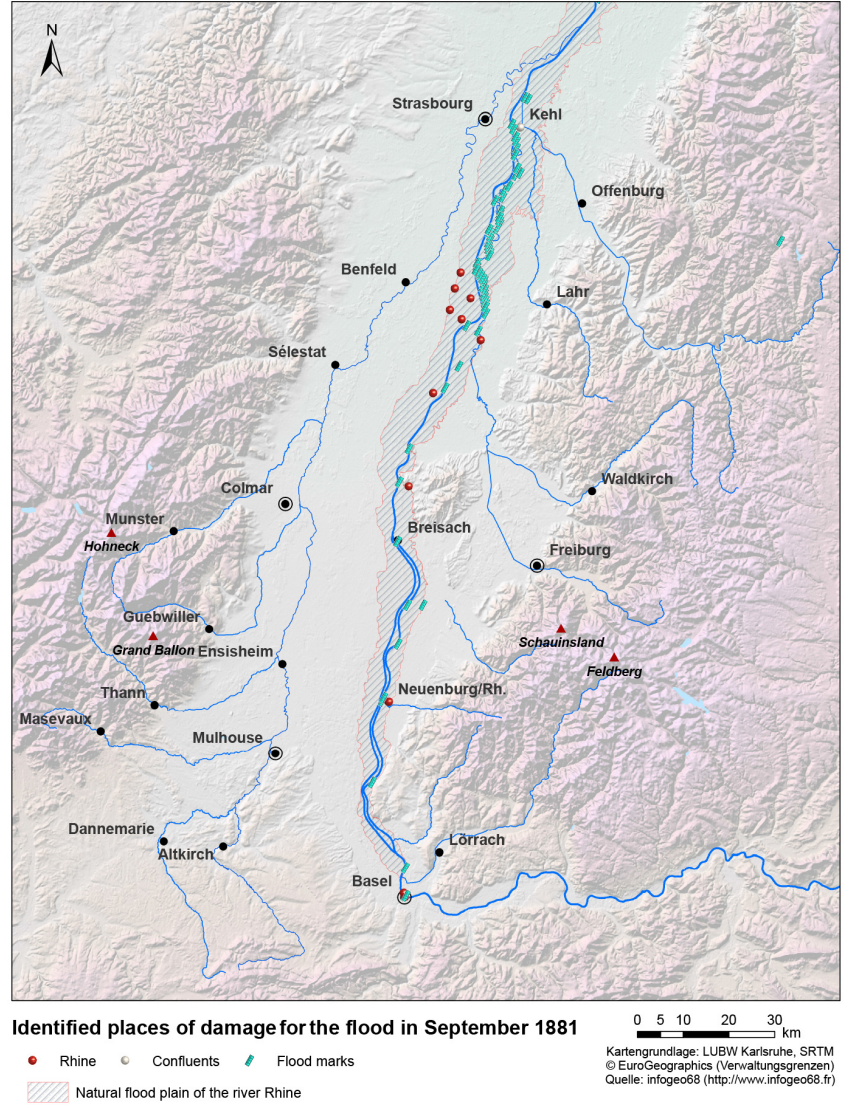

Figure 2. Damage map of the flood in September 1881 (Type 1).

However, it has to be taken into account that from 1817 onwards the massive alterations in the context of the rectification of the River Rhine system by Tulla and successors likely increased awareness to even minor flood events, and the installation of numerous new gauging stations raised the availability of data. This alone might lead to interpret the rise in number of flood events as a result of data, which, of course, provides no reasonable explanation for the observed decline of flood events. All other decades from 1500 to present day did not show a distinct emphasis towards one season. The only exception could be the period between the 1940s and the 1970s where winter runoff dominated (see Fig. 8). In contrast to the period around the 1950s where the elevated winter runoff did not occur in conjunction with extreme events (see Fig. 10), the period at the ending of the LIA was, at least last to a certain degree, induced by big and extreme events.

Looking at the two most important tributaries of the River Rhine in the study area (the French Ill and the German Kinzig) it is noticeable, that up to the present day no major changes in the flood regime have taken place (Figs. 10-13). It is evident that most flood events occur during the hydrological winter half-year with a strong increase in the total number since the second half of the 18th century. This however can most likely be attributed to a data-related signal. Further- 


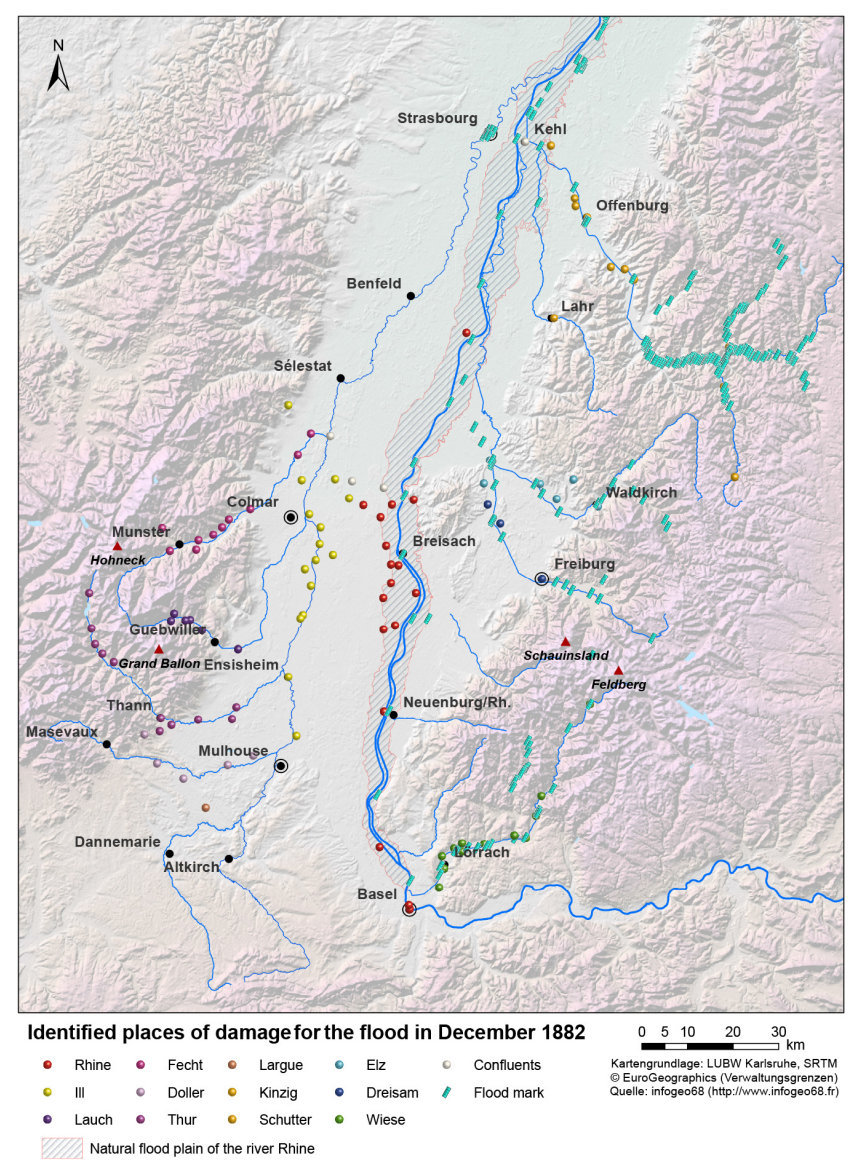

Figure 3. Damage map of the flood in December 1882 (Type 2).

more, the Ill displays a noteworthy increase in summer flood events recently, which however is not triggered by extreme flood events.

\section{Transboundary aspects of flood protection}

The different legal traditions of France and Baden led to different flood protection concepts that exist in their essential features until today. The significant differences developed in the 17th century. Until that time, flood protection on the nonnavigable rivers was a particular interest of all those who had to or wanted to protect something alongside the river. Here the differences can be seen between the towns and the rural communities: rich towns, like e.g., Strasbourg, were able to protect their goods very well until wars or economic crisis made it impossible to pay the price for the flood protection or military needs required a change. The little communes, i.e., their habitants, had to protect their land on an unpaid basis, so only the most critical points were protected with dams, which were furthermore not constructed with technical knowledge, so in most cases their protection level was not very high and the lifespan of those actions was limited.

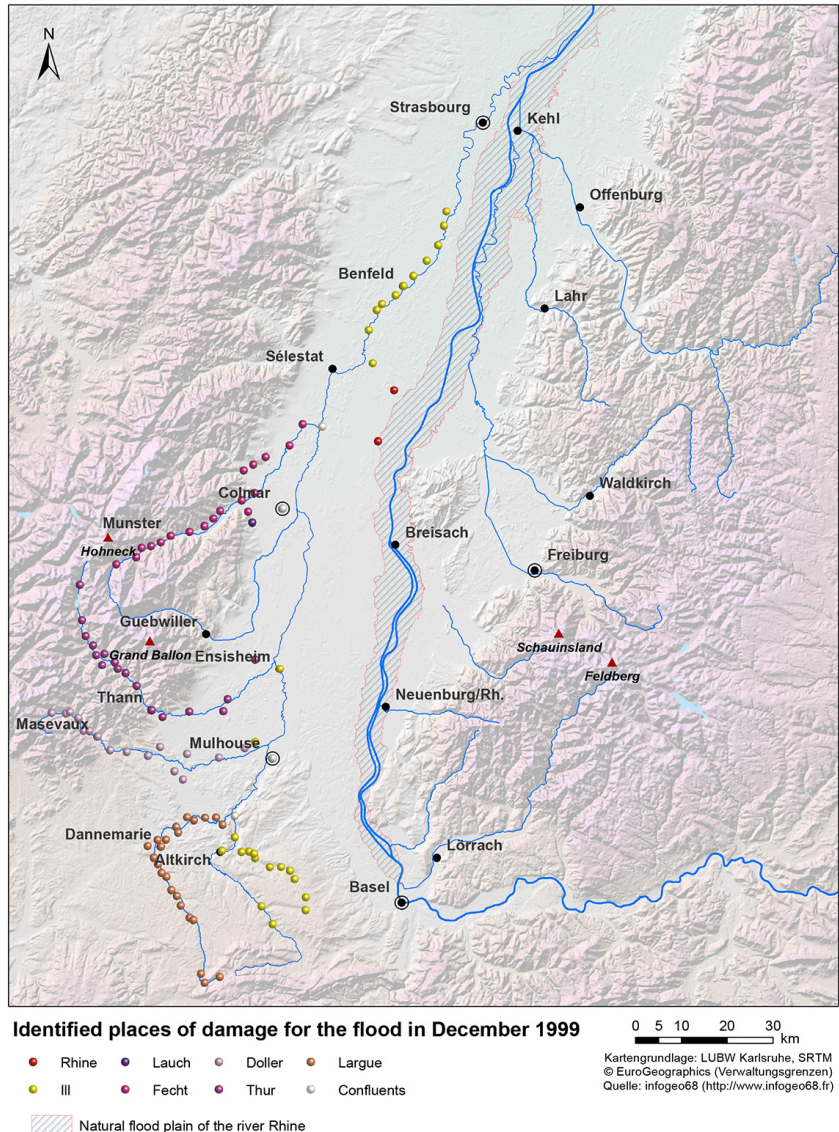

Figure 4. Damage map of the flood in December 1999 (Type 3).

For the navigable rivers, like the River Rhine, there was not a big difference between the French and the German part of the research area regarding flood protection measurements: both sides relied on dams, sluices and other flood protection projects since the 18th century. For the German part of the research area many particular states had been responsible, e.g., the Duchy of Baden, the Habsbourg Monarchy and many sovereign landlords. That lead to the fact that the quality of flood protection was not only a technical question but also a question of financial opportunities and was coordinated neither between the different German authorities nor with the French side. However, the legal situation on both sides was similar: the responsibility for navigable rivers was of the highest authorities, but action was not always taken. In later times, all contracts and plans could be handled out between the representatives of the states of France and the Grand Duchy of Baden. In 1840 the controlled and planned development of the River Rhine according to the plans and projects of Johann Gottfried Tulla (1770-1828) started (Himmelsbach, 2014).

The real difference in terms of flood control developed between Baden and France along the non-navigable rivers. To underline the political and administrative dimension of flood 


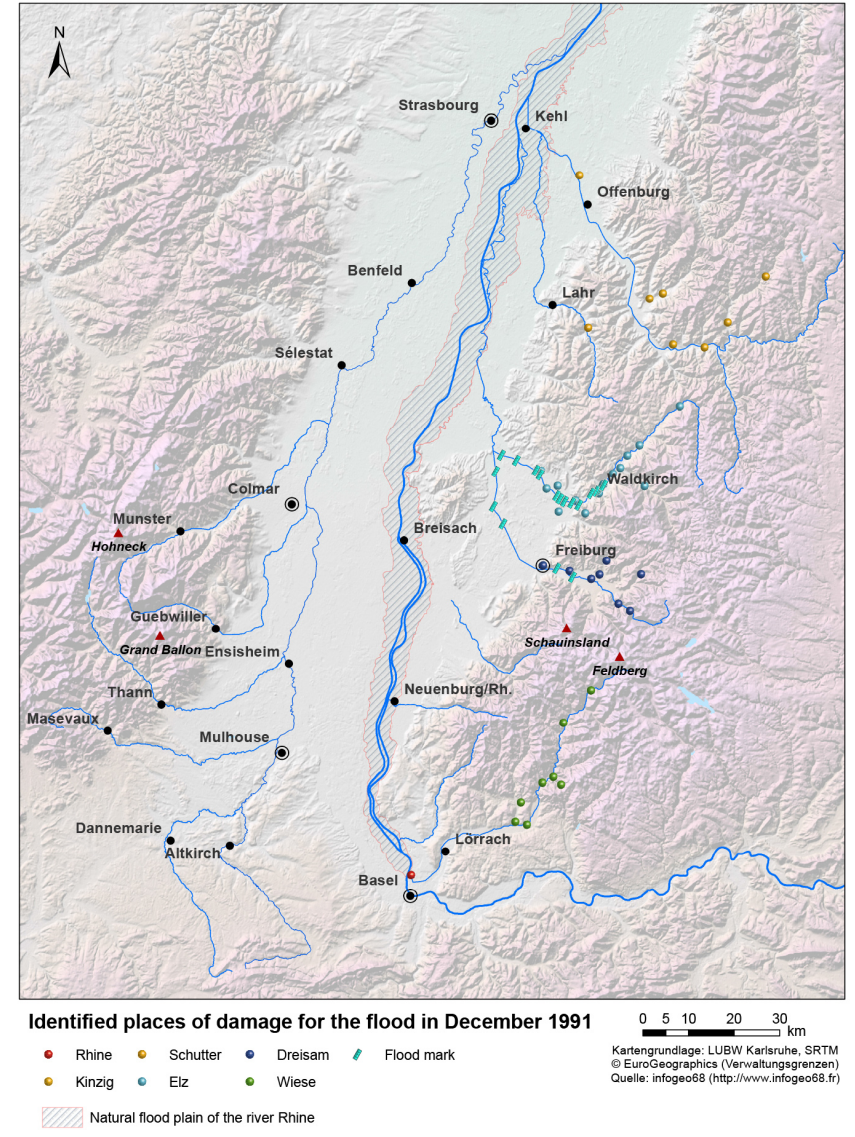

Figure 5. Damage map of the flood in December 1991 (Type 4).

control it is necessary to analyze the different laws, bylaws and regulations concerning the flood control.

In France the riparian rights are based on the Roman law, which means in this case that every landowner and commune had to protect their land and goods for themselves. In other words, the non-navigable rivers were part of the owner's property. Only with their permission the administration one could implement plans of flood protection. The start of the so-called administration of the "Ponts et chaussées" in 1716 in Alsace, the French government tried to get access to at least the roads and bridges for military and economic connections from Paris to the River Rhine. In the following decades many bridges across the non-navigable rivers were renewed or built. But bigger and continuous flood protection projects were not possible because of the water-rights. Only where towns paid for the work of the administration could limited projects have been brought forward, like the canal protecting Mulhouse (see Sect. 5.3.3). Neither the French administration after the revolution of 1789 nor the German administration between 1871 and 1919 were able to get full access on these kinds of rivers. In the end, flood protection in Alsace on the non-navigable rivers developed more as a chain of random individual actions, which led to the consequence

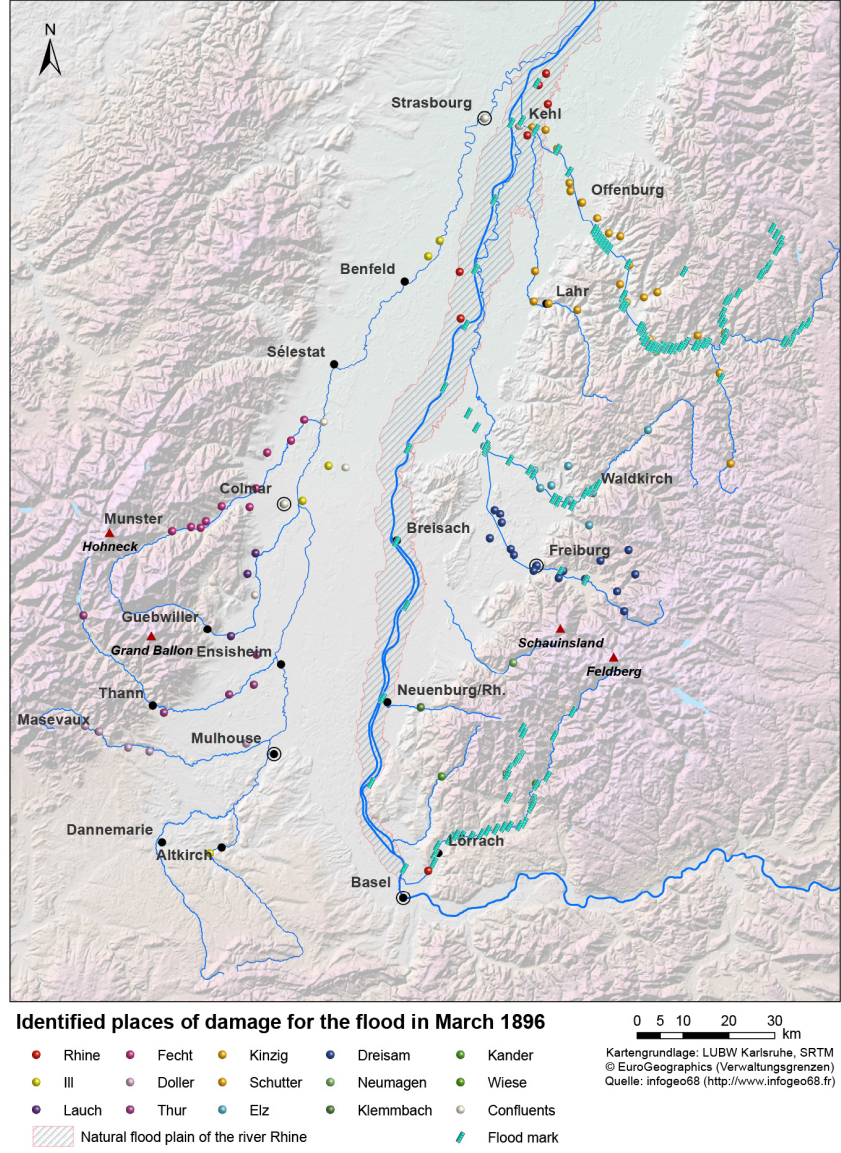

Figure 6. Damage map of the flood in March 1896 (Type 5).

that the natural flood plains of the rivers had to be respected as a potentially unsafe area to settle.

In the German part of the study area the Grand Dutch of Baden followed another tradition of law: since 1716, parts of the River Murg (outside the study area) were rectificated to protect the town of Rastatt it was obvious that the administration had no problem seeing the non-navigable rivers as part of their responsibility. That claim has been unchallenged since. The German riparian rights were first fixed in the so-called "Sachsenspiegel" in the beginning of the 13th century. The non-navigable rivers became part of the feudal system, which means that the feudal landowner had all rights on them. Without that legislation the work of Johann Gottfried Tulla and those who followed him would have never happened. In the state of the Grand Duchy of Baden the first attempt to work on the non-navigable rivers was done in 1816 by founding the first river training syndicate of the Grand Duchy of Baden (1. Großherzoglich-Badischer Flussbauverband), which was a result of the engagement of Johann Gottfried Tulla. The fact that the state incurred two-thirds of river construction costs offered on some rivers a "win-win situation" between the state and the riparian the communities. On other rivers, e.g., the Wiese, some communities left the syn- 
Changes of the meteorological causes of the floods [\%] in the last 50 years (all events)

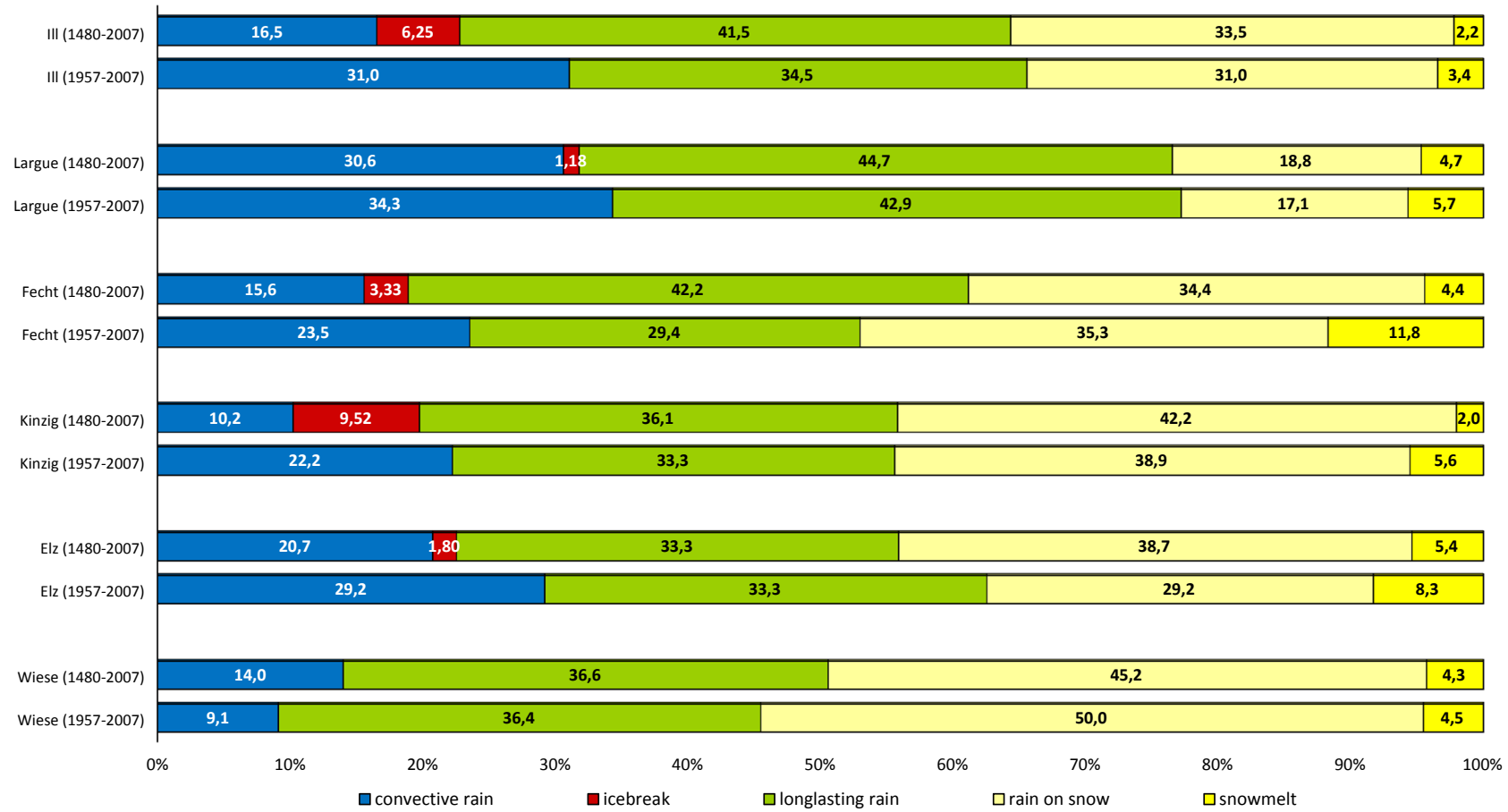

Figure 7. Changes of the meteorological causes of the floods in the last five decades in comparison to the period from 1480 to 2007.

31 yr running mean of floods in the hydrological year: River Rhine (all events (1480-2007))

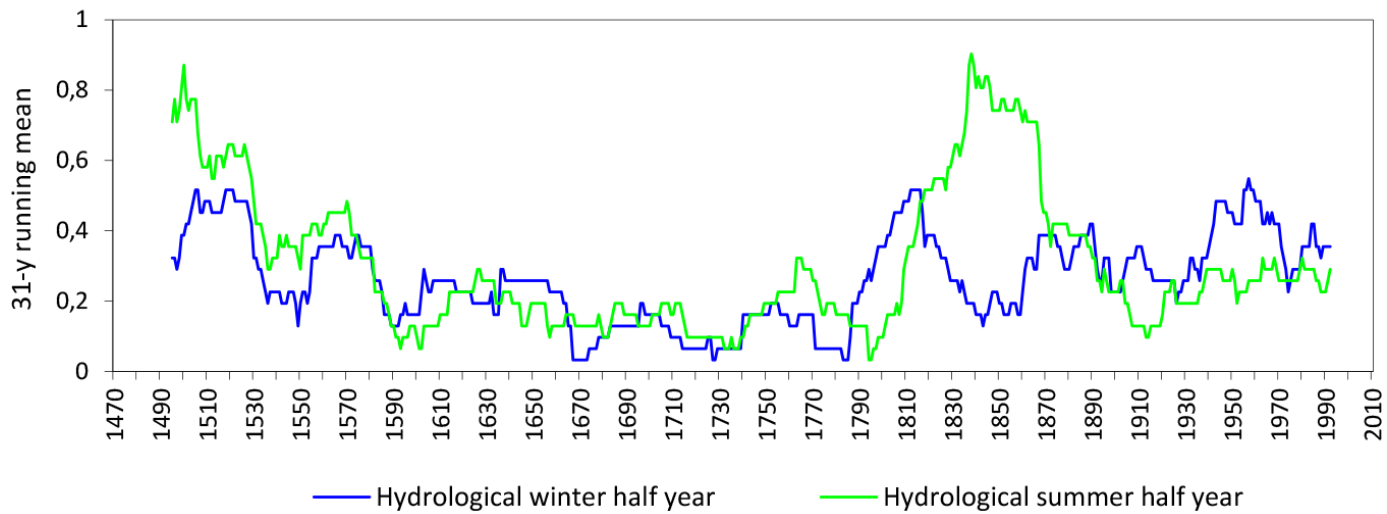

Figure 8. Floods of the River Rhine in the hydrological summer and winter years (all events).

dicate (1822) to rejoin in 1882 after some serious floods (Bär, 1870; Zentralbüro für Meteorologie und Hydrographie des Großherzogtums Baden, 1887). Up to the middle of the 19th century nearly all non-navigable rivers in the Grand Duchy of Baden were canalized.

In Alsace the riparian rights prohibit technical flood protection outside the towns on the non-navigable rivers. The attempt of the French government to challenge that by launching the so-called "river training syndicates" (Syndicats fluviaux) failed because of the complicated structures and the in- sufficient support by the administration but most frequently because of the divergent interests of the members which had been ordered into them. One part was only interested in water for agricultural needs, the other part was the industry (mainly from draperies), which wanted to canalize the rivers to get constant water into their factories and to protect them against flooding. The farmers worried that a canalization of the rivers would hinder the irrigation of their land. This conflict could not be solved neither by the French nor by the German administrations after 1871 . The only bigger project that 


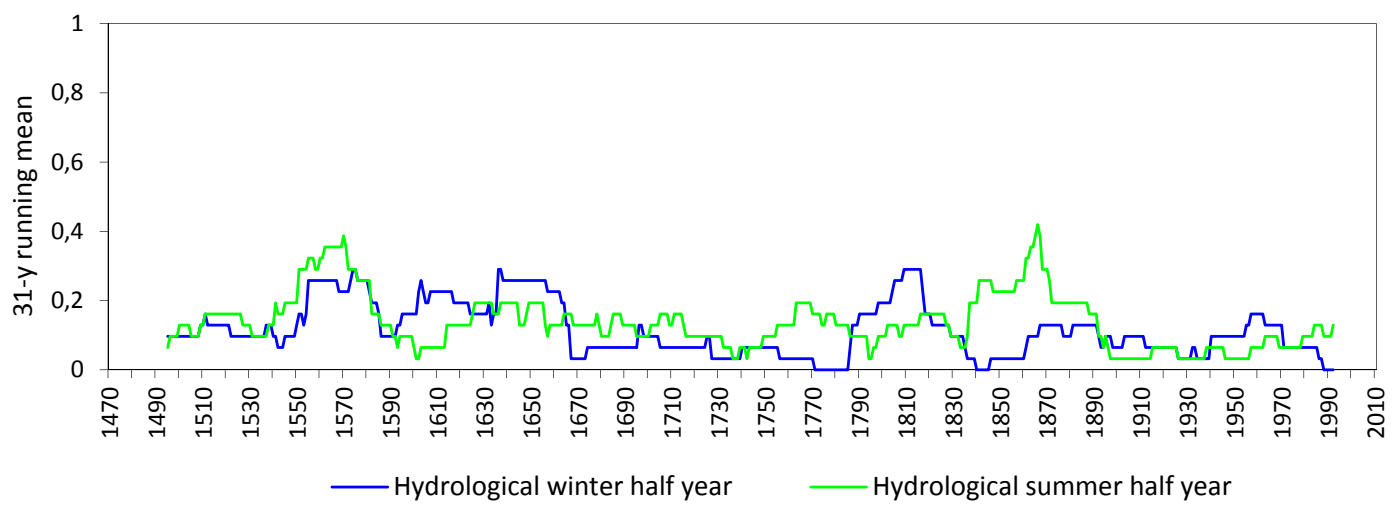

Figure 9. Floods of the River Rhine in the hydrological summer and winter years (big and extreme events).

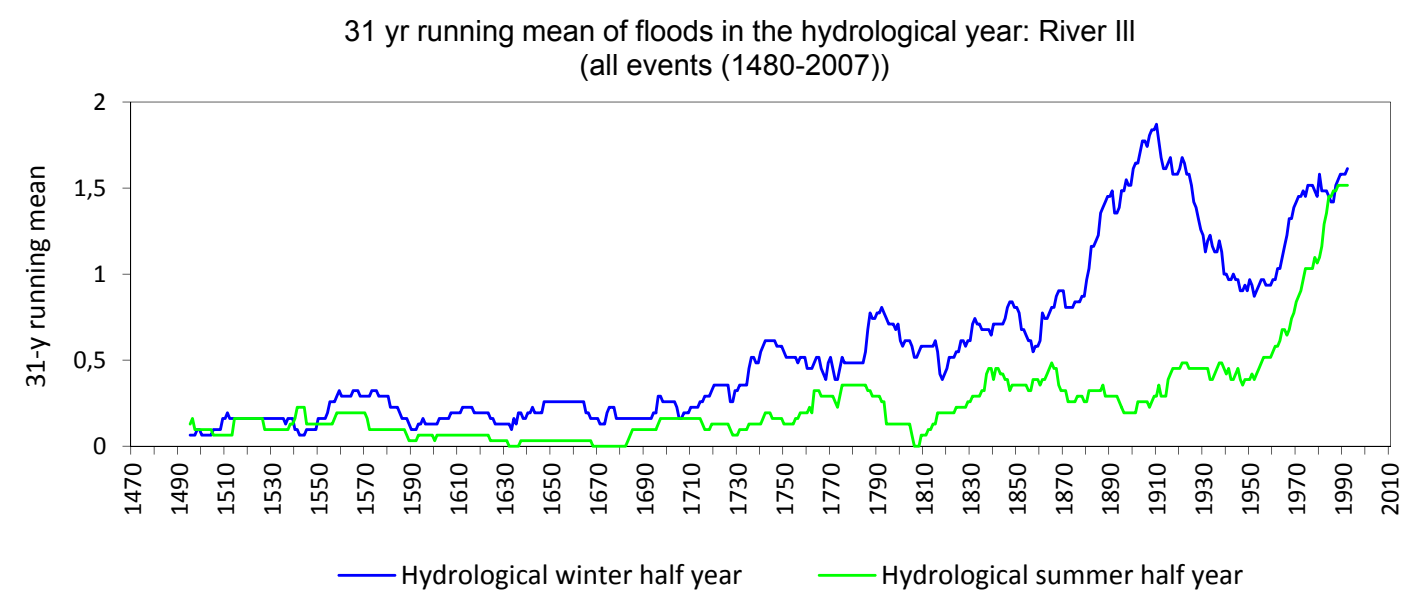

Figure 10. Floods of the River Ill (Alsace) in the hydrological summer and winter years (all events).

was done was the correction work on the River Ill between Meyenheim and Colmar between 1878 and 1888 (Bordmann, 2004; Himmelsbach, 2014).

In the long term, these different concepts of flood protection led to two different points of view regarding the natural stream channel: in Baden all rivers were canalized, while in Alsace no significant flood protection was archived and the natural flooding areas needed to be respected. In BadenWürttemberg the attitude evolved that behind the technical flood protection systems one can build nearly anything, from industrial areas to apartment houses. Now, as the European flood risk management directive from 2007 (EU, 2007) is implemented by publishing the flood and risk maps, a big and controversial discussion has started in the concerned communities regarding the consequences for the private people and the enterprises who reside near the rivers. What will happen to the prices of their properties along the rivers (and behind the dams) and what possibilities will the enterprises have in the industrial areas (which in many cases were placed in the natural flood areas) if they want to expand?

\subsection{Vulnerability analysis}

Historical sources provide not only information about floods and climate but also about damages and impacts on society, which can be used to analyze the vulnerability and resilience aspects. Both, hazards and vulnerability are fundamental elements of risk analysis. One major task of the TRANSRISK project is to bridge modern and historical information.

While there are convincing examples concerning flood events and hazard analysis, the concepts to evaluate vulnerability are subject of recent and future research. Integrating historical gauging data for definition of return periods like the mega-flood of 2002 in Dresden leads to a significantly changed reassessment of this important parameter. Taking the gauging data from 1879 to 2002 into account in comparison to merely using the data for the time period from 1936 to 2002 changes the return period from HQ1000 to HQ150 (Grünewald, 2010). A case study for the extreme flood event of 1824 on the River Neckar at Stuttgart showed that flood events, water level, return period and rainfall intensity were 
$31 \mathrm{yr}$ running mean of floods in the hydrological year: River III (heavy and extreme events (1480-2007))

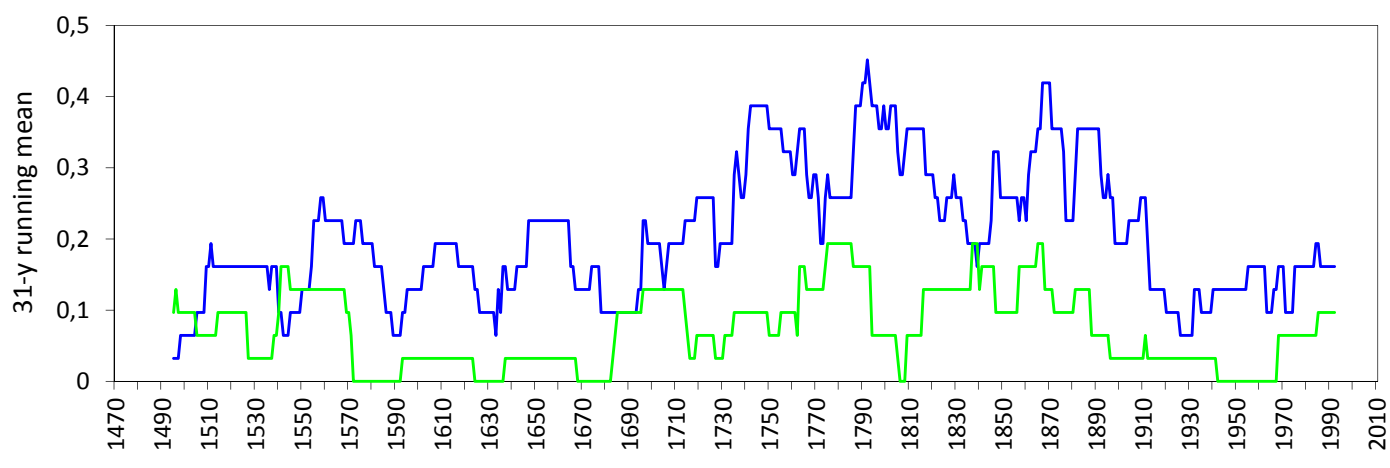

Hydrological winter half year

Hydrological summer half year

Figure 11. Floods of the River Ill (Alsace) in the hydrological summer and winter years (big and extreme events).

31 yr running mean of floods in the hydrological year: River Kinzig (all events (1480-2007))

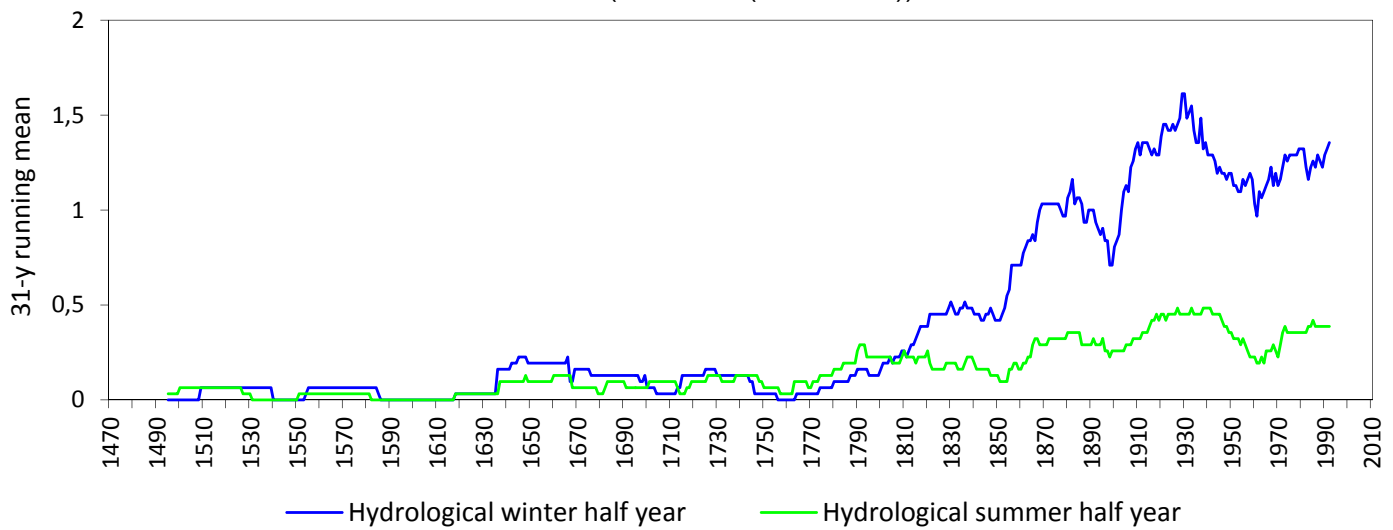

Figure 12. Floods of the River Kinzig (Baden-Württemberg) in the hydrological summer and winter years (all events).

underestimated using modern data alone. For this purpose, historical data on precipitation patterns and intensity and inundation areas were incorporated into the modern hydrological budget model LARSIM (Large Area Runoff Simulation Model; Bürger et al., 2006) and led to a redefined design flood for the River Neckar. Pfister et al. (1999) underlined the importance of the social dimension, which can be regarded as the first step for vulnerability assessment.

The following examples for the rivers Dreisam and Mulhouse demonstrate, how HQ100 events can be used for a better understanding of the spatial dimension of the flood extents and damages and to evaluate vulnerability aspects integrating parts of modern and historical flood risk management.

For the tributaries of the River Dreisam, the flooded areas at the water bodies of category II east of Freiburg have been compared with the modern HQ50 and HQ100 flood-prone areas as lined out by the administration authorities as part of the risk maps of the European water directive (EU, 2007; Santato et al., 2013; Kjellgren, 2013). The actual status of the bridges within a HQ100 or higher event was added to underline our point of the missing flood protection of the water bodies of category II.

For Mulhouse it was possible to reconstruct the buildprocess of the so-called "Canal de décharge", a major part of the flood protection system of Mulhouse, which was started in the early 19th century; an example of the historical dealing with flood risk management accompanied by technical problems.

\subsubsection{River Dreisam: flood of March 1896 vs. December 1991}

For parts of the German River Dreisam catchment area it was possible to summarize and map the damages which were caused by two HQ100 events. To show the differences between the damage of the two flood events, we worked with raster maps $(1: 25000)$ to get a spatial view of the concentration of the damages, e.g., on bridges, sluice dams and the areas which were flooded. We normalized the damage in four 


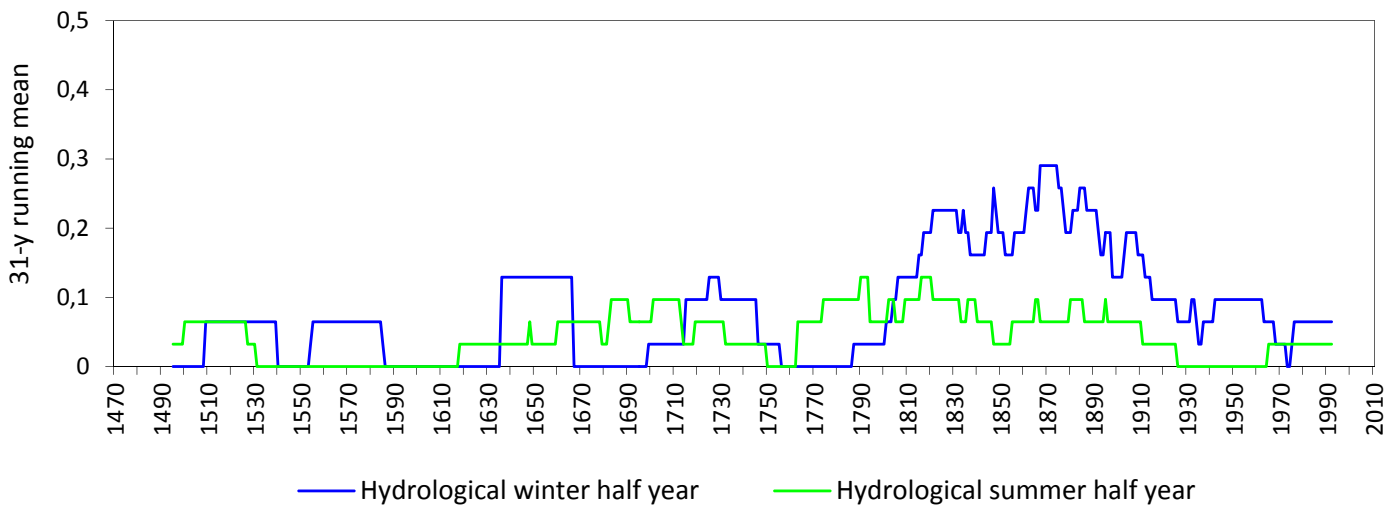

Figure 13. Floods of the River Kinzig (Baden-Württemberg) in the hydrological summer and winter years (big and extreme events).

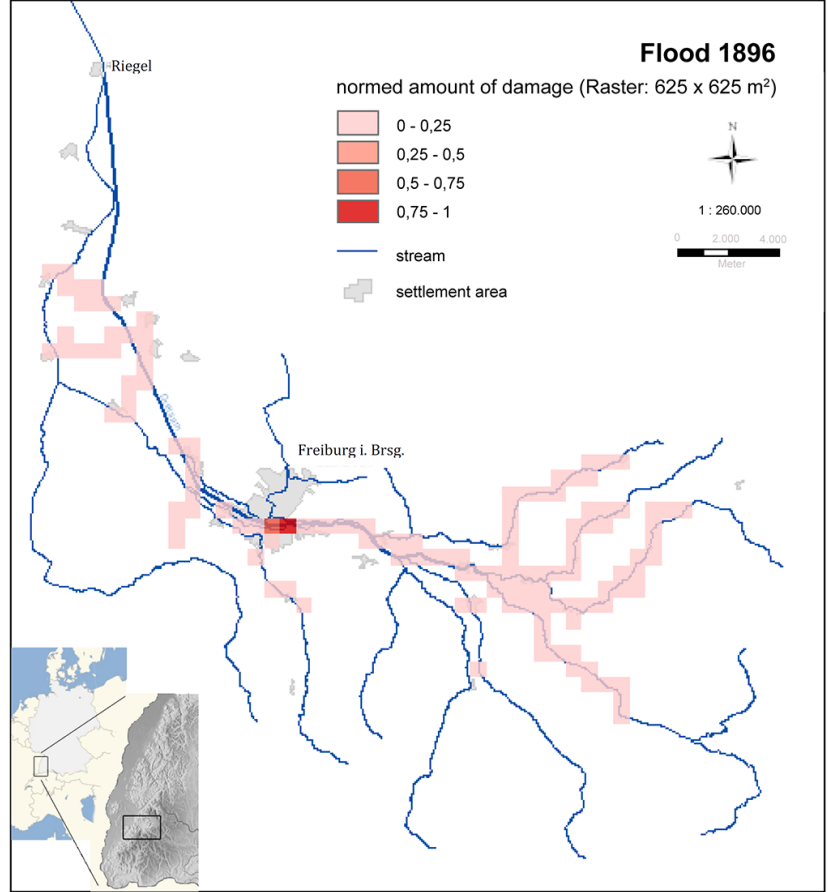

Spatial damage raster of the Dreisam catchment area

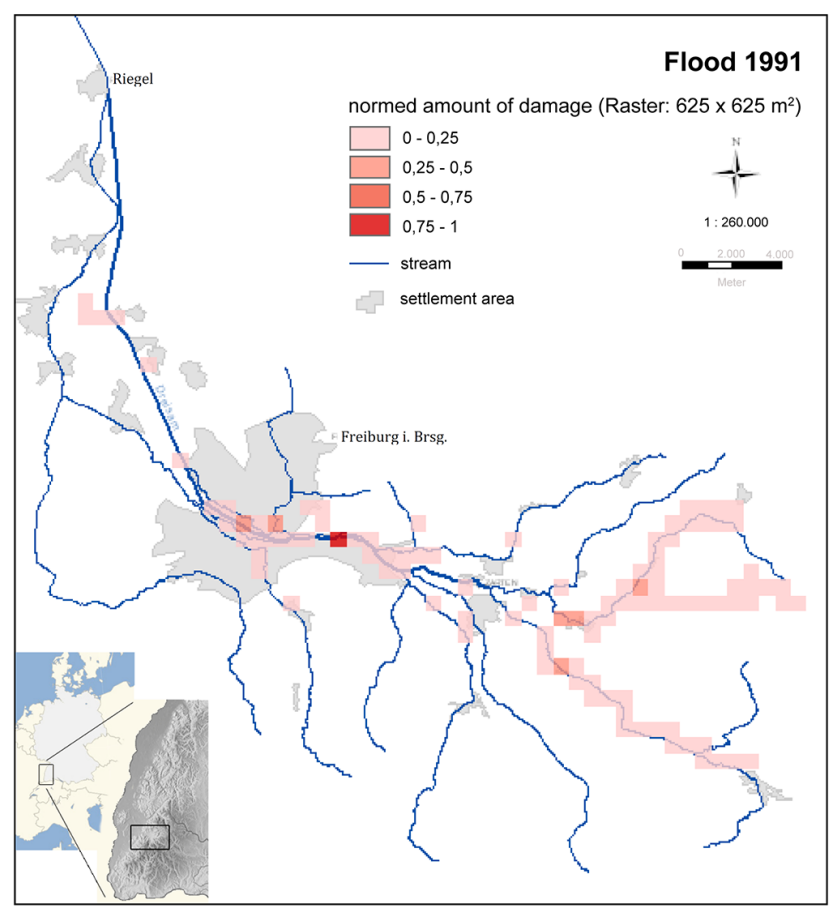

Spatial damage raster of the Dreisam catchment area

Figure 14. Normed damages of the floods from March 1896 (left) and December 1991 (right) near Freiburg.

classes from "no damage" (white) to "high damage" (red) (Jeworutzki, 2010).

In Fig. 14, different patterns for the damages can be observed which are specific to each flood situation. For the inner city of Freiburg the comparison shows that the damages in 1896 were more concentrated along the Dreisam River itself, while for the flood of 1991 it was more disperse around the modern city and also touched a canal in the city. The map of the accumulative damages for 1896 shows that the smaller villages like Zarten were much more affected by the flood than the city of Freiburg.

The background for this observation is the fact that the east parts of the city of Freiburg (some of the tributaries of the River Dreisam) were and are not protected in the same way against floods: there are no dams along the river and the creeks. Moreover, there was an increase of human activities during the last 100 years in this region, concerning settlements and industrial areas. The displayed tributaries are waterbodies of the category II, and the responsibility of their 


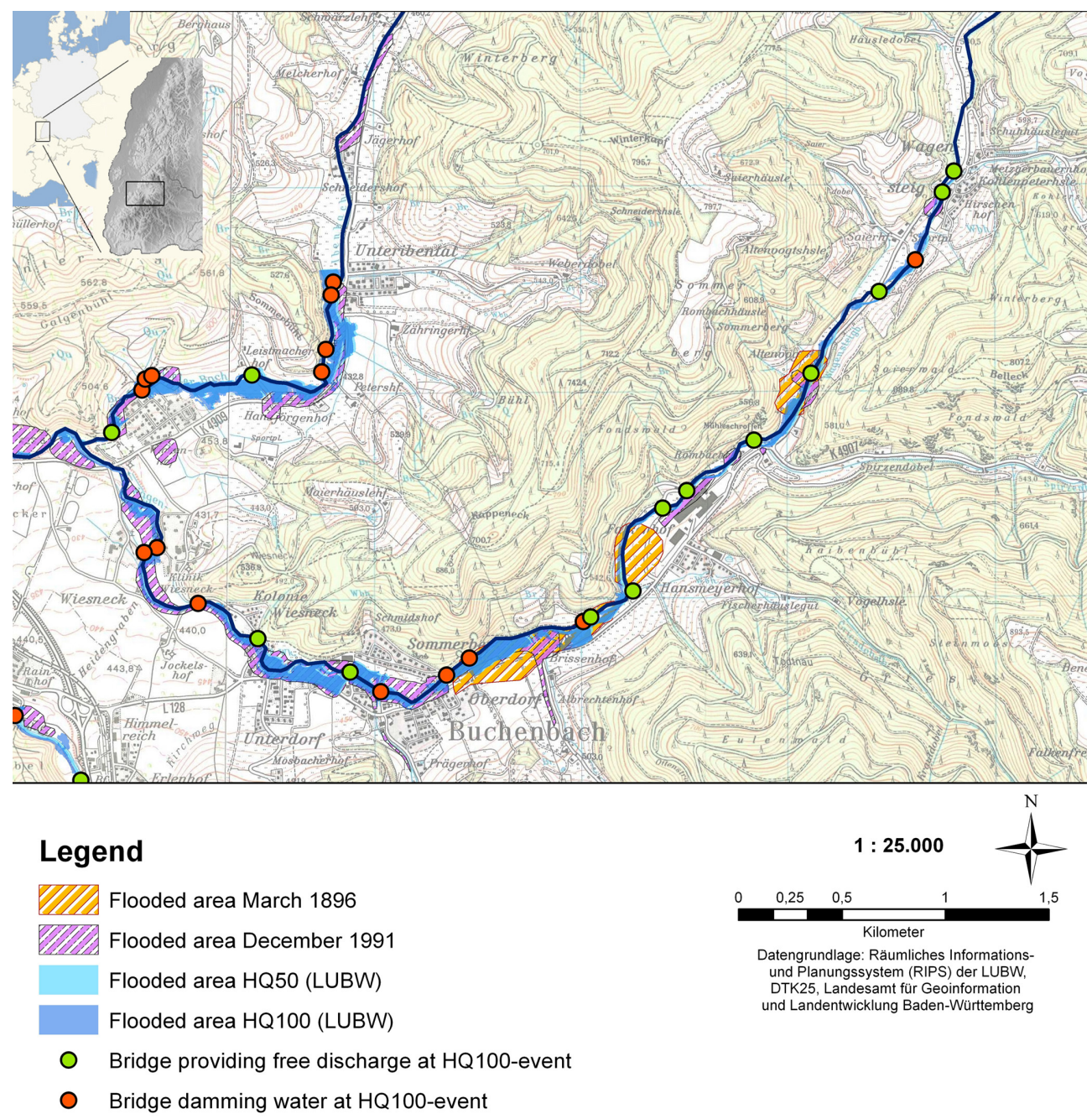

Figure 15. Comparison of flooded areas of 1896 and 1991 with modern HQ50 and HQ100 inundation areas as published by LUBW as part of the EU water directive (EU, 2007).

flood protection lies in the hands of the communities, which did not have the financial resources and/or the knowledge with which to take the needed actions. Both developments led to the fact that the pattern of the damages on the tributaries have not changed very much between 1896 and 1991. However, in the upper parts of the researched creeks more damage was caused. In addition it has to be noted that due to a multitude of reasons the available data is in all likelihood not complete. So the spatial distribution of the damages might to a certain degree also be influenced by the data availability.

\subsubsection{Comparison of flooded areas of $\mathbf{1 8 9 6}$ and 1991 with modern HQ50 and HQ100 risk maps}

The comparison of the flooded areas of the 1896 and 1991 floods with modern HQ50 and HQ100 inundation areas as published by LUBW (Regional planning authority of Baden-
Württemberg) as part of the EU water directive (EU, 2007) shows that the modeled areas do not always correlate with those which actually have been flooded in recent events. In addition it seems that important actions have not been taken since 1991. So bridges and their bases were not up to a HQ100 event because they are either weakly constructed or their spread was too small so that swells could be caused (Fig. 15). Even if the results from past flood events cannot be translated into modern times without adaptation, the comparison of the flooded areas from the 1896 and 1991 events with the expected flood area of a future HQ100 event demonstrates that at a local scale the necessary (technical) development of the creeks and rivers is not only a question of perception but also of planning intervals, communication processes with the affected local administration, the financial priorities and the acceptance of the planned measures by the residents. 


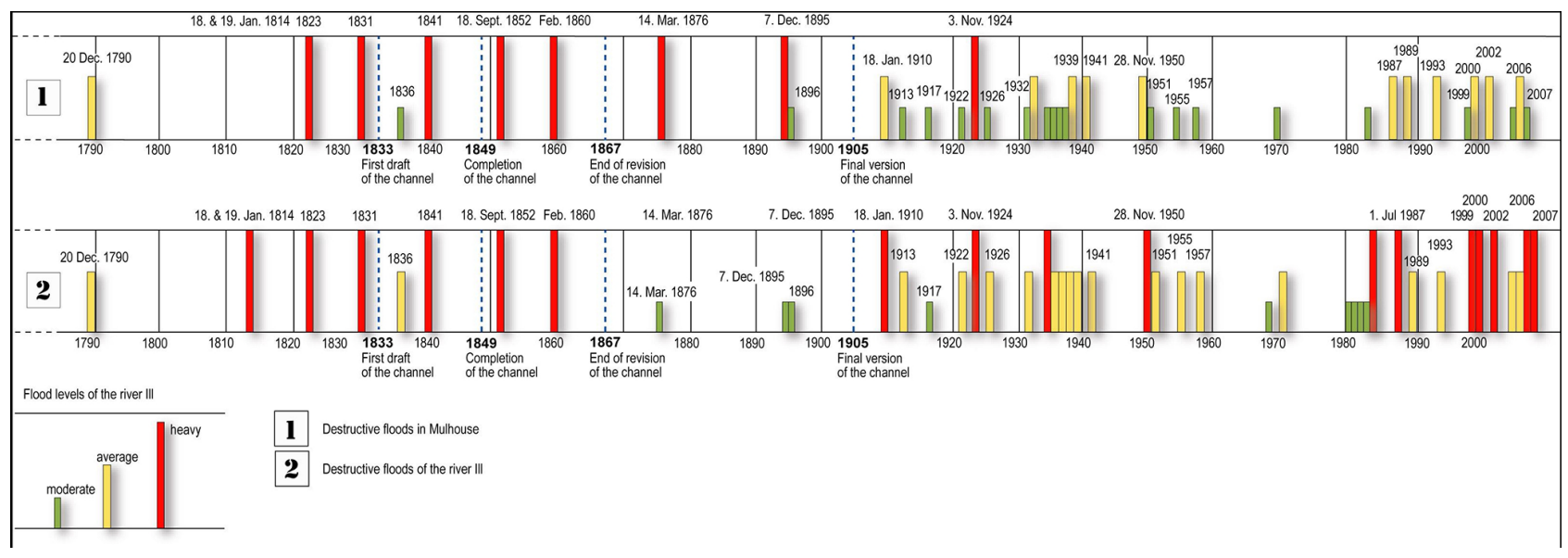

Figure 16. Changes in flood intensity due to technical alterations in Mulhouse.

\subsubsection{Mulhouse - changes in flood frequency due to technical alterations}

For the city of Mulhouse and the River Ill an analysis shows that technical alterations, in the case of Mulhouse the building of a diversion canal (Canal de décharge), had positive effects on limiting flood events and flooding of the city of Mulhouse. There has been only one major flood event, in 1924, since the establishment of this bypassing channel. The situation is very different for the rest of the Ill Basin, where such strong technical alterations were not possible due to water rights.

In Fig. 16, an inventory of the historic floods in the basin of the Ill and a classification in a scale of three levels of damage is shown. Two separate chronologies are displayed in order to compare the evolution of the number and intensity of the damaging floods, respectively, in Mulhouse and in the rest of the Ill Basin.

The comparison between the two chronologies turns out to be very instructive for the evaluation of the process of increasing the safety from floods for Mulhouse, which is mainly due to the role of the channel. Its construction has an impact on the random effects of flooding (due to its indirect influence on the dynamics of floods) and thereby on the vulnerability of the city, through the protection it provides, enabling the urbanization, which became possible after its completion.

Until 1860 there was a high coherence between floods in Mulhouse and the rest of the basin as to the number and intensity of the floods. So, the efficiency of the diversion canal has only progressively become manifest. There was a huge demand for building land and the urbanization (factory buildings and housing estates) was carried out in parallel with and even in anticipation of the construction of the canal.

The new quarters for the working class and new industrial areas were built on land which was highly liable to be flooded, so that the vulnerability rises. This was owed to the weakness of the earlier versions of the canal. Conversely, after the year 1905, when the final version of the canal was completed, Mulhouse appears clearly marked off from the rest of the Ill Basin, with fewer and above all less damaging floods (Martin et al., 2010, 2011).

\section{Conclusions}

The French-German transboundary project TRANSRISK demonstrates that it is feasible to identify records and evaluate historical flood events on both sides of the border with high temporal and spatial resolution from documentary sources by using a common classification scheme. Often the source itself contains additional information which allow for detailed insights into flood hazard and flood hazard perception. The derived 500-year-long flood chronology identified different spatial patterns of flood concurrencies which reveal local, regional and supraregional dimensions of flood events. The identification of flood triggering meteorological causes allows identifying changes in the climatological flood regime.

Regarding the sociopolitical context, flood control was exploited for political objectives in many time periods on both sides of the border. The border is clearly reflected in the risk perception but also risk management and risk assessment. This aspect clearly shows the different history of both nations as far as legal water rights are concerned, which leads to different ways of flood protection: the German side set focused on a technical development of the rivers. In Alsace this was legally not possible so the flood plains remained an unsafe place to be and had to be avoided.

The examples of the River Dreisam and Mulhouse show that the derivation of damage maps from historical sources as part of the vulnerability analysis is also possible. Especially, the example of the River Dreisam shows that the vulnerability on minor tributaries could increase if the flood protection 
measurements will not keep pace with the development of the human occupations of the riverside. Since 2007 the flood risk management is controlled by the EU policies (EU, 2007) which do not extend to small tributaries; flood risk management remains the responsibility of the communities.

In future, it is necessary to focus on risk perception, risk acceptance and the communication structures between the administration and the concerned persons regarding the implementation of flood protection systems also on minor tributaries in congested areas. This could lead to a comprehensive and integrative flood risk management. The aim should be a holistic understanding of the flood risk management, which traces the changing aspects in perception, policy decisions, assessment of technology and the role of risk and public discourse at the interface between climate change and social conceptualization in their temporal dynamics.

Edited by: R. Brazdil

\section{References}

Bär, F. J.: Die Wasser- und Strassenbau-Verwaltung in dem Grossherzogthum Baden, Karlsruhe, 1870.

Bauer, L.: Hydrologie des Flussgebietes von Unstrut und Gera unter besonderer Berücksichtigung der Hochwassererscheinungen und des Einflusses von Kahlschlagflächen auf die Wasserführung, Jena, 1952.

Bordmann, G.: Les colères de l'Ill aux environs d'Oberentzen et Oberhergheim, Annuaire - Société d'histoire de la Hardt et du Ried, 51-62, 2004

Bürger, K., Dostal, P., Seidel, J., Imbery, F., Barriendos, M., Mayer, H., and Glaser, R.: Hydrometeorological reconstruction of the 1824 flood event in the Neckar River basin (southwest Germany), Hydrol. Sci. J., 51, 864-877, 2006.

EU: EU flood risk management directive (2007/60/EC), http://eur-lex.europa.eu/legal-content/EN/TXT/?uri=CELEX: 32007L0060 (last access: 1 September 2015), 2007.

Glaser, R. and Stangl, H.: Historical floods in the Dutch Rhine Delta, Nat. Hazards Earth Syst. Sci., 3, 605-613, doi:10.5194/nhess-3-605-2003, 2003.

Glaser, R., Riemann, D., Schönbein, J., Barriendos, M., Brázdil, R., Bertolin, C., Camuffo, D., Deutsch, M., Dobrovolný, P., van Engelen, A., Enzi, S., Halícková, M., Koenig, S., Kotyza, O., Limanówka, D., Macková, J., Sghedoni, M., Martin, B., and Himmelsbach, I.: The variability of European floods since AD 1500, Climatic Change, 101, 235-256, 2010.

Glaser, R., Riemann, D., Himmelsbach, I., Drescher, A., Schönbein, J., Martin, B., and Vogt, S. (Eds.): Analyse historischer Hochwasserereignisse - Ein Beitrag zum Hochwasserrisikomanagement, in: WBW Fortbildungsgesellschaft für Gewässerentwicklung mbH, Erfahrungsaustausch Betrieb von Hochwasserrückhaltebecken in Baden-Württemberg, Berichtsband der 18. Jahrestagung, 8-17, 2012

Grünewald, U.: Zur Nutzung und zum Nutzen historischer Hochwasseraufzeichnungen, Hydrologie und Wasserbewirtschaftung, 2, 85-91, 2010.
Himmelsbach, I.: Erfahrung - Mentalität - Management. Hochwasser und Hochwasserschutz an den nicht-schiffbaren Flüssen im Ober-Elsass und am Oberrhein (1480-2007), Freiburger Geographische Hefte Nr. 74, 2014.

Internationale Kommission für die Hydrologie des Rheingebietes (Eds.): Das Abflussregime des Rheins und seiner Nebenflüsse im 20. Jahrhundert, Analyse, Veränderungen, Trends (= Bericht Nr. I-22 der KHR), 2007.

Internationale Kommission zum Schutz des Rheins (Eds.): Szenarienstudie für das Abflussregime des Rheins, Stand April, 2011.

Jacobeit, J., Glaser, R., Luterbacher, J., Nonnenbacher, M., and Wanner, H.: Links between flood events in central Europe since AD 1500 and the large-scale atmospheric circulation, in: V.R. Thorndycraft, G. Applications in Flood Risk Assessment Verlag, 269-274, 2003a.

Jacobeit, J., Glaser, R., Luterbacher, J., and Wanner, H.: Links between flood events in central Europe since AD 1500 and largescale atmospheric circulation modes, Geophys. Res. Lett., 30, 1172, doi:10.1029/2002GL016433, 2003 b.

Jacobeit, J., Philipp, A., and Nonnenmacher, M.: Atmospheric circulation dynamics linked with prominent discharge events in Central Europe, Hydrol. Sci. J., 51, 946-965, 2006.

Jeworutzki, A.: GIS-gestützte Analyse hochwasserinduzierter Schadwirkungen an der Dreisam, MSc thesis, unpublished, University of Freiburg, Freiburg, 2010.

Kjellgren, S.: Exploring local risk managers' use of flood hazard maps for risk communication purposes in BadenWürttemberg, Nat. Hazards Earth Syst. Sci., 13, 1857-1872, doi:10.5194/nhess-13-1857-2013, 2013.

Martin, B., Ansel, R., Drescher, A., Guerrouah, O., Glaser, R., Riemann, D., Vitoux, M.-C., Vogt, S., and With, L.: Threatening disaster or masterd risk? A geo-historical approach of flood risk in urban area, Example of Mulhouse (France), Territorium, 17, 201-209, 2010.

Martin, B., Ansel, R., Guerrouah, O., Vitoux, M.-C., With, L., Drescher, A., Glaser, R., Himmelsbach, I., and Schönbein, J.: Géohistoire critique de la crue de janvier 1910 dans le Fossé Rhénan (Alsace /Pays de Bade), La Houille Blanche, 1, 62-68, 2011.

Max-Planck-Institut für Meteorologie (Ed.): REMO - Regionale Klimasimulationen für Deutschland, Österreich und die Schweiz, 2006

Pfister, C.: Klimageschichte der Schweiz 1525-1860 Bern, Stuttgart, 1985.

Pfister, C., Brázdil, R., and Glaser, R. (Eds.): Climatic Variability in Sixteenth Century Europe and Its Social Dimension, in: Climatic Change, Special Volume, 43, 111-150, 1999.

Santato, S., Bender, S., and Schaller, M: The European Floods Directive and Opportunities offered by Land Use Planning, CSC Report 12, Climate Service Center, Germany, 2013.

Seidel, J. and Bárdosy, A.: Berücksichtigung von historischen Hochwasserereignissen in der Extremwertstatistik, Geographische Rundschau (03/2010), 42-47, 2010.

Weischet, W. and Endlicher, W. (Ed.): Regionale Klimatologie, Teil 2: Die Alte Welt: Europa, Afrika, Asien, Stuttgart, 2000.

Wetter, O. and Pfister, C.: Das Jahrtausendhochwasser von 1480 an Aare und Rhein, in: Berner Zeitschrift für Geschichte, 4, 1-10, 2011.

Wetter, O., Pfister, C., Weingartner, R., Luterbacher, J., Reist, T., and Trösch, J.: The largest floods in the High 
Rhine basin since 1268 assessed from documentary and instrumental evidence, Hydrolog. Sci. J., 56, 733-758, doi:10.1080/02626667.2011.583613, 2011.

Zebisch, M., Grothmann, T., Schröter, D., Hasse, C., Fritsch, U., and Cramer, W.: Klimawandel in Deutschland-Vulnerabilität und Anpassungsstrategien klimasensitiver Systeme, Berlin, Umweltbundesamt, 2005.
Zentralbüro für Meteorologie und Hydrographie des Großherzogtums Baden: Der Binnenflussbau im Großherzogtum Baden, Beiträge zur Hydrographie des Großherzogtums Baden, Heft, 5, 1887. 